\section{Root Severance at Harvest Increases Embolism and Decreases Sap Flow of Field-grown Acer rubrum L.}

\author{
Patricia R. Knight ${ }^{1}$, J. Roger Harris ${ }^{2}$, and Jody K. Fanelli ${ }^{3}$ \\ Department of Horticulture, Virginia Polytechnic Institute and State \\ University, Blacksburg, VA 24061
}

Additional index words. red maple, cavitation, hydraulic conductance, stomatal conductance

\begin{abstract}
Root severance during field harvesting alters the water status of a tree, resulting in water stress and reduced post-transplant growth. Two experiments, using Acer rubrum L. (red maple), determined the influence of root severance at harvest on sap flow and xylem embolism. Trees 1.5-1.8 m tall (4 years old) were utilized in the first experiment, and trees $1.2-1.5 \mathrm{~m}$ tall ( 2 years old) were utilized in the second. Sap flow sensors were installed on the 4-year-old trees prior to root severance and remained on the trees until 1 week after harvest. Within 1 day after root severance sap flow was reduced and remained lower than nontransplanted (control) trees for the remainder of the experiment. Leaf stomatal conductance $(\mathrm{Cs})$ of transplanted trees 1 week after root severance was lower than that of control trees, but leaf water potentials $(\psi)$ were similar. In the second experiment, sap flow was reduced relative to control trees within 2 h after root severance. Although Cs was reduced 4 hours after root severance, $\psi$ was not. Embolism increased within 24 hours of root severance. These results indicate that root severance quickly induces increased levels of embolism, which is associated with reduced sap flow.
\end{abstract}

A well-watered, established tree may lose water from the leaf surface at a rate $>60$ $\mathrm{g} \cdot \mathrm{m}^{-2} \cdot \mathrm{h}^{-1}$ on a warm, sunny day (Vrecenak and Herrington, 1984). Transplanting can greatly alter tree water status (Grossnickle, 1988; Harris and Gilman, 1993; Kaushal and Aussenac, 1989). For example, root loss during transplanting may restrict water uptake, resulting in water stress (Grossnickle, 1988; Watson and Kupkowski, 1991). Blake (1993) reported an increase in stomatal resistance $8 \mathrm{~d}$ after nonstored Picea glauca (Moench) Voss seedlings were transplanted, but the difference was not apparent after $14 \mathrm{~d}$. Root damage reduced transpiration of Picea trees that survived transplanting, but water potential $(\psi)$ was similar (Coutts, 1982).

Sperry et al. (1994) reported that low $\psi$ associated with drought stress is a primary cause of cavitation, leading to embolism. Cavitation is the phase change of water from a liquid to a gas, and an embolism is the air bubble remaining in the vessel (Milburn and Johnson, 1966; Sperry et al., 1994). Embolism can reduce hydraulic conductance, thus inhibiting transpiration (Schultze and Matthews,

\footnotetext{
Received for publication 5 Mar. 1998. Accepted for publication 18 Aug. 1998. Mention of trade names does not imply endorsement of products named nor criticism of similar products not used. The cost of publishing this paper was defrayed in part by the payment of page charges. Under postal regulations, this paper therefore must be hereby marked advertisement solely to indicate this fact.

${ }^{1}$ Former Graduate Assistant. Current address: Mississippi State Univ., South Mississippi Branch Experiment Station, P.O. Box 193, Poplarville, MS 39470.

${ }^{2}$ Associate Professor

${ }^{3}$ Research Technician.
}

1988; Sperry and Pockman, 1993). Sperry and Pockman (1993) reported reduced leaf stomatal conductance $(\mathrm{Cs}) 2 \mathrm{~d}$ after injection of air to induce cavitation, but leaf $\psi$ was not influenced. Dixon et al. (1984) reported that dehydration of Thuja occidentalis L. decreased leaf $\psi$, but that subsequent release of stem water reserves after cavitation rehydrated the foliage. Stomatal closure coincided with foliar rehydration.

Understanding changes in tree water status during transplanting permits measures to be taken to improve transplant survival. The objective of this research was to determine if root severance of red maple trees induced embolism and if this increased embolism was associated with reduced sap flow.

\section{Materials and Methods}

Expt. 1. Two-year-old, bareroot Acer rubrum L. 'Franksred' (J. Frank Schmidt and Sons, Boring, Ore.) were planted at the Urban Horticulture Center near Blacksburg, Va., in a Groseclose silty clay loam (clayey, mixed, Typic Hapludult) with a $\mathrm{pH}$ of 6.5 in Apr. 1994. On 26 May 1996, eight uniform trees were selected $(1.5-1.8 \mathrm{~m}$ tall and $1.9-2.5 \mathrm{~cm}$ stem diameter measured $15.2 \mathrm{~cm}$ above the soil line), and sap flow sensors (SGB 16-WS Dynagauge; Dynamax, Houston) were placed at various heights on the main stem, below all foliage. All sensors were covered with a weather shield, openings sealed with silicone, and the entire sensor apparatus and the portion of the stem below the gauge to the ground covered with aluminum foil to prevent interference from solar radiation (Steinberg et al., 1989). This system uses heat balance technology (Baker and van Bavel, 1987; Ham and Heilman, 1990; Sakuratani, 1981). Sap flow $\left(\mathrm{mg} \cdot \mathrm{h}^{-1}\right)$ was recorded at 60 -s intervals $(\mathrm{CR} 21 \mathrm{X}$ data logger; Campbell Scientific, Logan, Utah) and averaged every $30 \mathrm{~min}$. Data $\left(\mathrm{mg} \cdot \mathrm{h}^{-1}\right)$ were reported as 24-h averages. On 31 May, four trees in full leaf that had not completed their first growth flush were randomly selected and root-severed with a $30-\mathrm{cm}$ rootball (American Association of Nurserymen, 1996). Trees were dug during an active growth phase to ensure the occurrence of high stress levels, completely lifted from the soil to ensure severance of all roots, and replaced in the original hole. Four randomly selected, nontreated trees served as controls. All plants were thoroughly irrigated after root severance. Sap flow measurements were continued for 6 d. At $1000 \mathrm{HR}$ on 7 June, both Cs and $\psi$ were measured on one fully expanded, east-oriented leaf per tree. Stomatal conductance was measured using a porometer (LI1600; LI-COR, Lincoln, Nebr.), and $\psi$ was measured with a pressure chamber (Soilmoisture Equipment Corp., Santa Barbara, Calif.). Light levels averaged $\approx 1200$ $\mu \mathrm{mol} \cdot \mathrm{m}^{-2} \cdot \mathrm{s}^{-1}$ during sampling. Total leaf area per plant was determined using a leaf area analyzer (LI-COR 3000). Flow rates were divided by leaf area to determine average flow $\left(\mathrm{mg} \cdot \mathrm{h}^{-1} \cdot \mathrm{cm}^{2}\right)$.

Embolism was measured on the portion of the stem covered by the sap flow sensor and the areas above and below the sensor $(\approx 30$ $\mathrm{cm})$. After being taken to the lab, stem segments were recut under water to a $20-\mathrm{cm}$ length to prevent entrance of air into cut stem ends (Sperry et al., 1994). Stem segments were then fitted with gaskets, retrimmed with razor blades, placed in parallel manifolds in the system (Sperry and Tyree, 1988), and percentage of embolism of stem segments was measured. The presence of embolisms was indicated by reduction in hydraulic conductance $\left(k_{h}\right)$ (Sperry et al., 1988), defined as $k_{h}=v /(d P / d l)$ where $v$ is the flow rate $\left(\mathrm{kg} \cdot \mathrm{s}^{-1}\right)$ and $d P / d l$ is the pressure gradient $\left(\mathrm{MPa} \cdot \mathrm{m}^{-1}\right)$. Initial and maximum $k_{h}$ were measured for each stem section. Stem segments were sequentially perfused with tap water using a hydraulic head of 3-5 kPa for measurement of initial $k_{h}$ (Sperry et al., 1988), then flushed with pressurized tap water at $150 \mathrm{kPa}$ for 15 min cycles until maximum $k_{h}$ was achieved. Reduction in hydraulic conductance (percentage of embolism) was calculated as percentage of embolism $=100$ (maximum $k_{h}$-initial $k_{h}$ )/maximum $k_{h}$.

Expt. 2. A second experiment was conducted to more closely pinpoint the stress responses seen in Expt. 1. The Acer rubrum L. trees (Lawyer Nursery, Plains, Mont.) were planted as 1-year-old seedlings at the Urban Horticulture Center near Blacksburg, Va., in Mar., 1995, in the same soil type as used for Expt. 1. Trees were $1.3-1.5 \mathrm{~m}$ tall, and stem diameters were $1.3-1.9 \mathrm{~cm}$. Stems were not actively enlongating. Sensor installation and statistical design were similar to those for Expt. 1. Four trees were root-severed at 1100 HR on 23 Aug. 1996, and four additional trees served as controls. About $0.5 \mathrm{~h}$ was required to root-sever all replications. Sap flow rate was measured every $60 \mathrm{~s}$ and stored as output by 
the data logger every $15 \mathrm{~min}$. Leaf Cs and leaf $\psi$ were recorded hourly between 1130 and 1630 HR. Light levels averaged $\approx 1250 \mu \mathrm{mol} \cdot \mathrm{m}^{-2} \cdot \mathrm{s}^{-1}$ for the sampling period. Percentage of embolism and predawn $\psi$ for each tree were determined on 24 Aug. All data were subjected to analysis of variance and Fisher's protected LSD, $P \leq 0.05$ (SAS ver. 6.03; SAS Institute, Cary, N.C.).

\section{Results and Discussion}

Expt. 1. Sap flow rate was reduced 1 day after root severance (1 June) (Fig. 1). Leaf Cs, measured at 1000 HR on 7 June 1996, 7 d after root severance (DARS), was also reduced in response to root severance (Table 1), while percentage of embolism was increased. Leaf $\psi$, at $1000 \mathrm{HR}$, measured 7 DARS, was not affected (Table 1).

Expt. 2. Sap flow was reduced within $2 \mathrm{~h}$ (Fig. 2) and Cs was reduced within $4 \mathrm{~h}$ of root severance (Fig. 3A). Leaf $\psi$ was unaffected (Fig. 3B), and predawn leaf $\psi$ was similar between treatments (data not shown). Percentage of embolism increased in root-severed trees within $24 \mathrm{~h}$ of root severance (Table 1).

Water loss averaged $\approx 40 \mathrm{mg} \cdot \mathrm{h}^{-1} \cdot \mathrm{cm}^{2}$ on 1 June in Expt. 1 (Fig. 1), and $\approx 60 \mathrm{mg} \cdot \mathrm{h}^{-1} \cdot \mathrm{cm}^{2}$ on 23 Aug. in Expt. 2 (Fig. 2) in control trees vs. 15 and $10 \mathrm{mg} \cdot \mathrm{h}^{-1} \cdot \mathrm{cm}^{2}$, respectively in rootsevered trees. Values for control trees for both experiments were higher than the $60 \mathrm{~g} \cdot \mathrm{h}^{-1} \cdot \mathrm{m}^{-2}$ reported by Vrecenak and Herrington (1984) for Acer platanoides L. and A. saccharum Marsh., but sap flow values of root-severed trees were closer to Vrecenak and Herrington's values. Deviations from Vrecenak and Herrington's (1984) results may be speciesspecific or be a function of the different environmental factors imposed on trees in the respective experiments. Trees in our experiment were allowed to grow in the field for at least 1 year prior to treatment. Therefore, they may have had greater root mass than container-grown trees in Vrecenak and Herrington's experiment. Additionally, hydraulic architecture may vary for field vs. container conditions, resulting in differences in available water (Bilderback, 1982). Other investigators have indicated that water uptake is restricted in transplanted plants because of root loss (Grossnickle, 1988; Kaushal and Aussenac, 1989). This was seen in our experiments as a reduction in stem sap flow soon after digging.

One week after harvest, Cs was $\approx 8.5$ times as great for control as for root-severed trees (Table 1). This reduction probably began within $4 \mathrm{~h}$ of root severance (Fig. 3A). This suggests that stomatal closure serves to minimize water loss and embolism resulting from water stress in transplanted trees. Tyree and Sperry (1988) demonstrated that many trees commonly live near the point of catastrophic embolism, and embolism levels are controlled by stomatal regulation. Dixon et al. (1984) reported that high levels of Cs were maintained until species-dependent low water potentials were reached, and then Cs was reduced. Data from our experiment agree with those of Blake

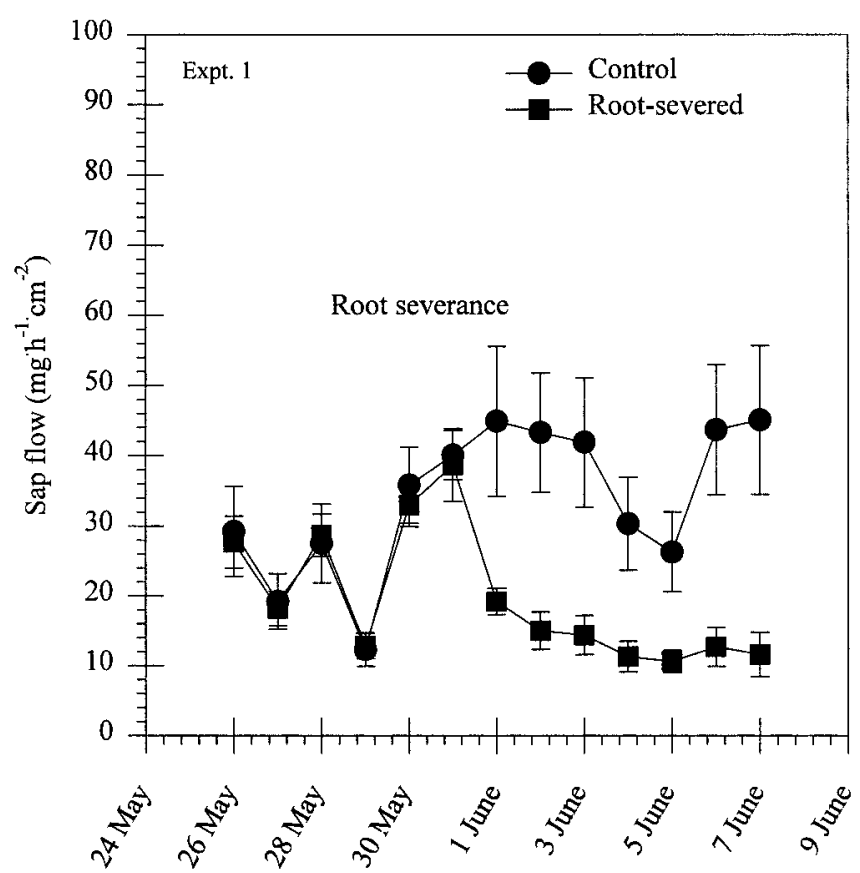

Fig. 1. Influence of root severance on sap flow in 4-year-old field-grown Acer rubrum L. Trees were harvested on 31 May 1996. Means that differ from the control according to to Fisher's protected LSD $(P \leq 0.05)$ are indicated by $*$. Vertical bars represent \pm SE of means, $\mathrm{n}=4$.

Table 1. Influence of root severance at harvest on leaf stomatal conductance (Cs), leaf water potential $(\psi)$, and percentage of embolism for field-grown Acer rubrum L.

\begin{tabular}{lcccr}
\hline & Cs & Leaf $\psi^{y}$ & \multicolumn{2}{c}{ Percentage of embolism } \\
\cline { 3 - 5 } Treatment & $\left(\mathrm{mmol} \cdot \mathrm{m}^{-2} \cdot \mathrm{s}^{-1}\right)$ & $(\mathrm{MPa})$ & Expt.1 & Expt. 2 \\
\hline Control & $199.8^{\mathrm{z}}$ & 0.18 & 40.0 & 43.8 \\
Root-severed & 23.4 & 0.13 & 49.5 & 85.4 \\
$P$ & 0.0030 & 0.1589 & 0.0003 & 0.0040 \\
\hline
\end{tabular}

${ }^{\mathrm{z}}$ Each value is the mean for one leaf on each of four plants.

${ }^{y}$ Measured at 1000 HR 7 June 1996 (Expt. 1 only).

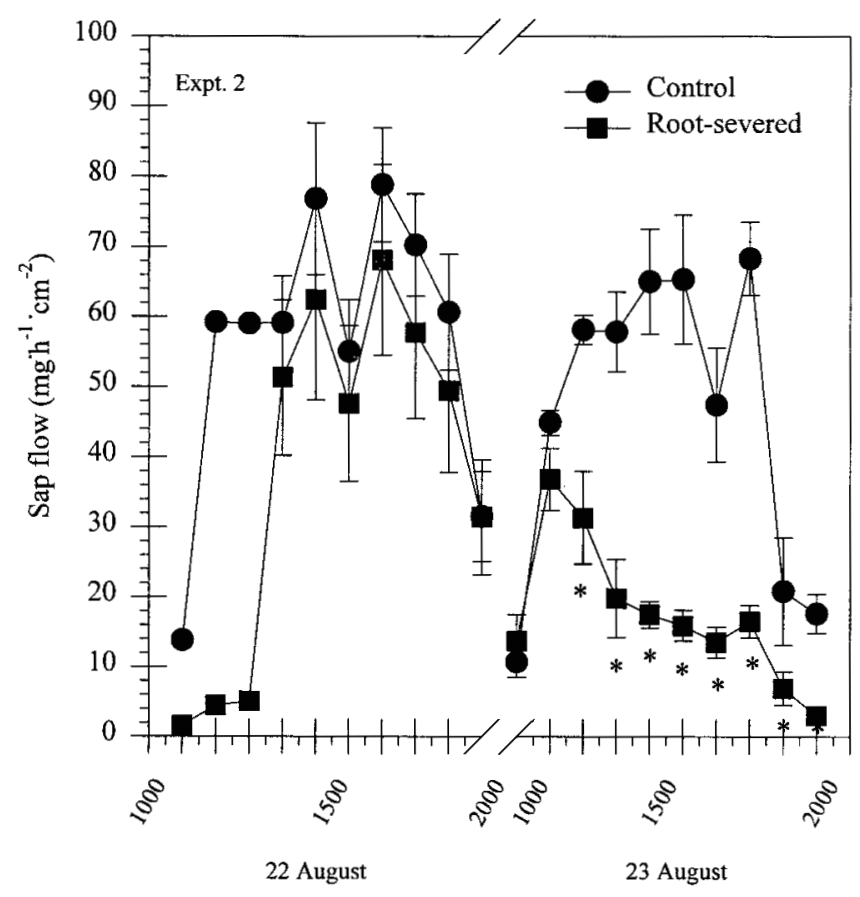

Day and hour

Fig. 2. Influence of root severance on sap flow for 2-year-old field-grown Acer rubrum L. Roots were severed at $1100 \mathrm{HR}$ on 23 Aug. 1996. Means that differ from the control according to to Fisher's protected LSD $(P \leq 0.05)$ are indicated by $*$. Vertical bars represent \pm SE of means, $\mathrm{n}=4$. 

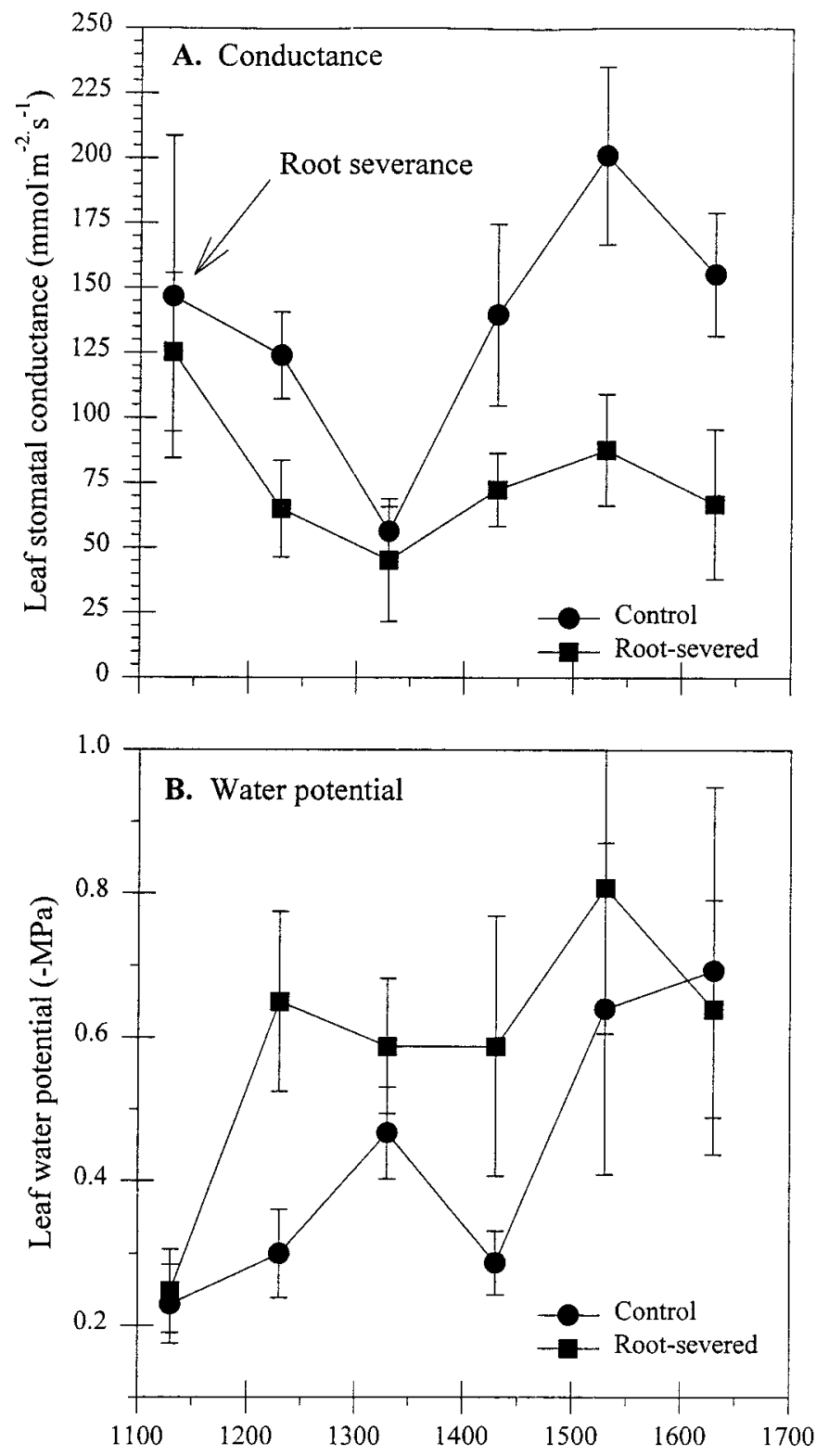

Time (HR)

Fig. 3. Influence of root severance on (A) leaf stomatal conductance and (B) leaf water potentials for 2-yearold field-grown Acer rubrum L. Roots were severed at $1100 \mathrm{HR}$ on 23 Aug. Means that differ from the control according to Fisher's protected LSD $(P \leq 0.05)$ are indicated by *. Vertical bars represent \pm SE of means, $n=4$.

(1993), who reported that Cs was reduced $8 \mathrm{~d}$ after bare-root Picea glauca (Moench) seedlings were transplanted. Harris and Gilman (1993) also reported reductions in Cs 3 and 5 $\mathrm{d}$ after transplanting field-grown holly (Ilex cornuta Lindl. \& Praxt. 'Burfordii'). Ferree (1989) and Ferree and Geisler (1984) reported that transpiration was reduced for Malus sp. between 10 and $28 \mathrm{~d}$ after transplanting. Coutts (1982) also reported reduced transpiration for root-damaged Picea sitchensis (Bong.) Carrière. Lack of Cs response for the $1630 \mathrm{HR}$ sampling time of $23 \mathrm{Aug}$. may be related to a decline in Cs of control trees resulting from stomatal closure, rather than to a recovery of $\mathrm{Cs}$ in root-severed trees (Fig. 3A). Reduced sap flow rates in control trees late in the afternoon support this conclusion.
Lack of $\psi$ response to root severance 6 DARS (Expt. 1, Table 1) or 23 Aug. (Expt. 2, Fig. 3B) may be related to trees reaching a critical $\psi$. This may have triggered massive levels of embolism at different times during the day because of differences in tree capacitance or root length within the rootball, rather than to lack of water stress. Individual trees in our experiment did follow the pattern outlined by Dixon et al. (1984) in which water potentials declined initially, increased temporarily, and then decreased again (data not shown). Coutts (1982) reported that $\psi$ did not decrease in Picea seedlings that survived transplanting, whereas the decline in $\psi$ was slow in seedlings that did not survive. Even though our experiment was conducted in the summer, when trees were in full leaf, all trees survived into the fall.
Coutts (1982) suggested that the delay in the development of substantial water stress, as indicated by reduced $\psi$, was due to a slow, progressive increase in resistance to water uptake in roots. However, reductions in sap flow that occurred soon (within $2 \mathrm{~h}$ ) after digging in Expt. 2 suggest that the lack of response of Acer rubrum leaf $\psi$ may be related to differences in transpiration lags between plants. Most plants exhibit a lag between transpiration and adsorption, and its duration may vary for different plants, depending on trunk/ stem capacitance or root density within the rootball (Kramer and Boyer, 1995).

Postharvest reductions in Cs and increases in embolism levels in our experiments agree with the data of Sperry et al. (1994), who reported that embolism reduces transpiration, and Sperry and Pockman (1993), who observed that the reductions continued for $2 \mathrm{~d}$. Xylem pressures of those plants were not influenced by increasing embolism. Dixon et al. (1984) noted that $\psi$ declined initially in dehydrated Thuja occidentalis L., then increased as a result of a rehydration event caused by embolism in the stem. The rehydration event, also recorded by Dixon et al. (1984) coincided with massive stomatal closure, followed by a slight decrease in leaf $\psi$ (Fig. $3 \mathrm{~A}$ and B). In agreement with the observations of Dixon et al. (1984), Cs of our trees was low at the end of Expt. 1 (Table 1).

Reductions in stem sap flow for Acer rubrum occurred relatively quickly after rootseverance, and preceded reductions in Cs. Exactly when embolism occurred after root severance is unknown, but based on the research of Dixon et al. (1984), it was probably between 2.5 and $4.5 \mathrm{~h}$ after root severance in Expt. 2. Reduced stem sap flow associated with postroot-severance embolism could potentially result in slow shoot growth (transplant shock), although more research is needed to clarify cause and effect.

\section{Literature Cited}

American Association of Nurserymen. 1996. American standard for nursery stock. Amer. Assn. Nurserymen, Washington, D.C.

Baker, J.M. and C.H.M. van Bavel. 1987. Measurement of mass flow of water in the stems of herbaceous plants. Plant Cell Environ. 10:777782.

Bilderback, T.E. 1982. Container soils and soilless media. North Carolina Agr. Ext. Serv. NCPM No. 9.

Blake, T.J. 1993. Transplanting shock in white spruce: Effect of cold-storage and root pruning on water relations and stomatal conditioning. Physiol. Plant. 57:210-216.

Coutts, M.P. 1982. Water relations of Sitka spruce seedlings after root damage. Ann. Bot. 49:661668.

Dixon, M.A., J. Grace, and M.T. Tyree. 1984. Concurrent measurements of stem density, leaf and stem water potential, stomatal conductance, and cavitation on a sapling of Thuja occidentalis L. Plant Cell Environ. 7:615-618.

Ferree, D.C. 1989. Growth and carbohydrate distribution of young apple trees in response to root pruning and tree density. HortScience 24:62-65. 
Ferree, D.C. and D. Geisler. 1984. Root pruning as a means of size control. Acta Hort. 146:269-275.

Grossnickle, S.C. 1988. Planting stress in newly planted jack pine and white spruce. I. Factors influencing water uptake. Tree Physiol. 4:71-83

Ham, J.M. and J.L. Heilman. 1990. Dynamics of a heat balance stem flow gauge during high flow. Agron. J. 82:147-152.

Harris, J.R. and E.F. Gilman. 1993. Production method affects growth and post-transplant establishment of 'East Palatka' holly. J. Amer. Soc. Hort. Sci. 108:194-200.

Kaushal, P. and G. Aussenac. 1989. Transplanting shock in Corsican pine and cedar of Atlas seedlings: Internal water deficits, growth and root regeneration. For. Ecol. Mgt. 27:29-40.

Kramer, P.J. and J.S. Boyer. 1995. Water relations of plants and soils. Academic, San Diego, Calif.

Milburn, J.A. and R.P.C. Johnson. 1966. The conduction of sap. II. Detection of vibrations pro- duced by sap cavitation in Ricinum xylem. Planta 69:43-52.

Sakuratani, T. 1981. A heat balance method for measuring water flux in the stem of intact plants. J. Agr. Meteorol. 37:9-17.

Schultze, H.R. and M.A. Matthews. 1988. Resistance to water transport in shoots of Vitis vinifera L.: Relation to growth at low water potentials. Plant Physiol. 88:718-724.

Sperry, J.S., J.R. Donnelly, and M.T. Tyree. 1988. A method for measuring hydraulic conductivity and embolism in xylem. Plant Cell Environ. 11:35-40.

Sperry, J.S., K.L. Nichols, J.E.M. Sullivan, and S.E. Eastlack. 1994. Xylem embolism in ring-porous, diffuse-porous, and coniferous trees of northern Utah and interior Alaska. Ecology 75:1736-1752.

Sperry, J.S. and W.T. Pockman. 1993. Limitation of transpiration by hydraulic conductance and $\mathrm{xy}$ - lem cavitation in Betula occidentalis. Plant Cell Environ. 16:279-287.

Sperry, J.S. and M.T. Tyree. 1988. Mechanisms of water stress-induced xylem embolism. Plant Physiol. 88:581-587.

Steinberg, S., C.H.M. van Bavel, and M.J. McFarland. 1989. A gauge to measure mass flow rate of sap in stem and trunks of woody plants. J. Amer. Soc. Hort. Sci. 114:466-472.

Tyree, M.T. and J.S. Sperry. 1988. Do woody plants operate near the point of catastrophic xylem dysfunction caused by dynamic water stress? Answers from a model. Plant Physiol. 88:574580.

Vrecenak, A.J. and L.P. Herrington. 1984. Estimation of water use of landscape trees. J. Arboric. 10:313-319.

Watson, G.W. and G. Kupkowski. 1991. Soil moisture uptake by green ash trees after transplanting. J. Environ. Hort. 9:226-227. 